\title{
Type-2 Diabetes mellitus is it Habitat Specific?
}

\author{
Murugan.A. \\ (Associate Professor and HOD of Zoology, S.T. Hindu College, Nagercoil - 629002, Tamil Nadu, India,
}

\begin{abstract}
Diabetes, the killer disease is a new threat to the modern world, which rattles the people irrespective of their race, culture, religion and boundaries. The disabilities produced by this devil, changes the affluent as ordinary and poor as paupers. Though it is multifactorial in nature, doubt prevails over the exact cause(s) of its emergence in man. It emerges as habitat non-specific and one of the major non-communicable diseases which draws attention to the modern man. The present study tries to analyze the impact of habitats in addition to socio-economic and anthropometric measures on the level of incidence of Diabetes mellitus in the people of Kanyakumari district, Tamil Nadu, India. The output of the present investigation on diabetes is explained by a hypothesis (i.e.) culprit hypothesis.
\end{abstract}

Key words: anthropometric measures, culprit hypothesis, pandemic, vegan, Western Ghats.

\section{Introduction}

Diabetes mellitus has emerged as a new avatar as one of the deadliest diseases in $21^{\text {st }}$ century and created huge economic loss due to shattered man power. This new pandemic seems to be a formidable challenge to the global community. Diabetes with its jet speed (1) makes the disease as a global menace (2). India is with the highest number of diabetics $(3,4)$ with both urban $(5-7)$ and rural cases $(8,9)$.

D.mellitus is a metabolic disorder with hyperglycaemia due to body's inability to produce insulin (or) resistance to insulin action (or) both (10). An array of risk factors like body mass index (BMI) $(11,12)$, waist-hip ratio (WHR) (13), age $(14,15)$, ethnicity $(16)$, family history $(16,17)$, diet $(18,19)$, sex $(14,20)$, many set of genes (21), socio-economic status (22) and systolic blood pressure (23) are found to be associated with the onset of diabetes in man.

Epidemiological studies on diabetes are only centered around rural/urban settlements and such studies on different habitats are very rare to evaluate the reasons for its prevalence in various spatially arranged settlements. Hence the present study has been carried out in midland and coastal areas to find out the habitat specific occurrence of diabetes. The main thrust areas of the study are : 1) to find out the prevalence of Type- 2 Diabetes mellitus (T2DM) in different settlements 2) to identify the various associated risk factors of the disease and 3) to understand the real culprits of this modern global menace.

\section{Study area(s)}

\section{Materials and methods}

The present study is undertaken in Kanyakumari district, Tamil Nadu, the southern terminus of the Indian sub-continent (24). The study includes 56 settlements which spreads both in the midland/plain area and the coastal region with a spread of more than $100 \mathrm{~km}$ on road.

\section{Study population}

The study includes a heterogeneous population of medically fit 3000 people of which $1410(47 \%)$ are men and 1590 (53\%) are women belonging to the three different categories (viz) Most backward, Backward and Forward communities.

Mukkuvar, a fishing community believed to have emerged from Ceylon (Srilanka), and noticed as one among the many groups of fisherfolk in the country (25-27). They have settled in the coastal ecosystem of this district comprising $68 \mathrm{Km}$ in length and is studded with 44 coastal fishing villages. The coastal environment is an interface between land and sea (28). Our fishermen subjects include 474(47.4\%) males and 526 (52.6\%) females of inhabitants of 18 settlements.

Nadars (BC) are very hard working and one of the prominent castes of Tamil Nadu, South India. The term 'Nadar' in Tamil literally means one who rules the land (29). In the district their settlements are noticed next to coastal zone upto the base of Western Ghats. Our Nadar subjects comprises 481(48.1\%) males and 519 $(51.9 \%)$ females of residents of 23 settlements.

Nairs are Forward caste (FC) affluent community settled in interior part of the district especially in the west and north western parts of Kanyakumari district (30). The Nair respondents include 455 (45.5\%) males and $545(54.5 \%)$ females residing in 15 settlements. 
Screening of diabetics are followed by the method described (31). Standard methods are used for the various anthropometric measurements [BMI (32), WHR (32), BP(33) and statistical analysis (34)]. Door to door visits have been made to collect the data by a standard questionnaire. More importance has been given to human values during the data collection and Ethics Committees' guidelines are strictly followed throughout the study.

\section{Results}

The overall diabetic prevalence in the population is $15.53 \%$ with $15.89 \%$ male and $15.22 \%$ female patients. Around $15.5 \%$ disease prevalence is noticed in Mukkuvars, a Most Backward Community (coastal inhabitants) with a share of $14.47 \%$ (70 cases) male and $16.16 \%$ (85 cases) female diabetics. $14.4 \%$ disease prevalence is noticed in Nadars, a Backward community (midland/plain area settlers) with $12.27 \%$ (60 cases) male and $16.18 \%$ (84 cases) female diabetic subjects. Likely in another midland settlers Nairs (Forward Community) are having $16.7 \%$ disease prevalence with $20.66 \%$ male (94 cases) and $13.39 \%$ ( 73 cases) female diabetics (Table.1).

Table.1. denotes the prevalence of diabetes in different regions.

( $N=3000$ subjects; 1410 males +1590 females)

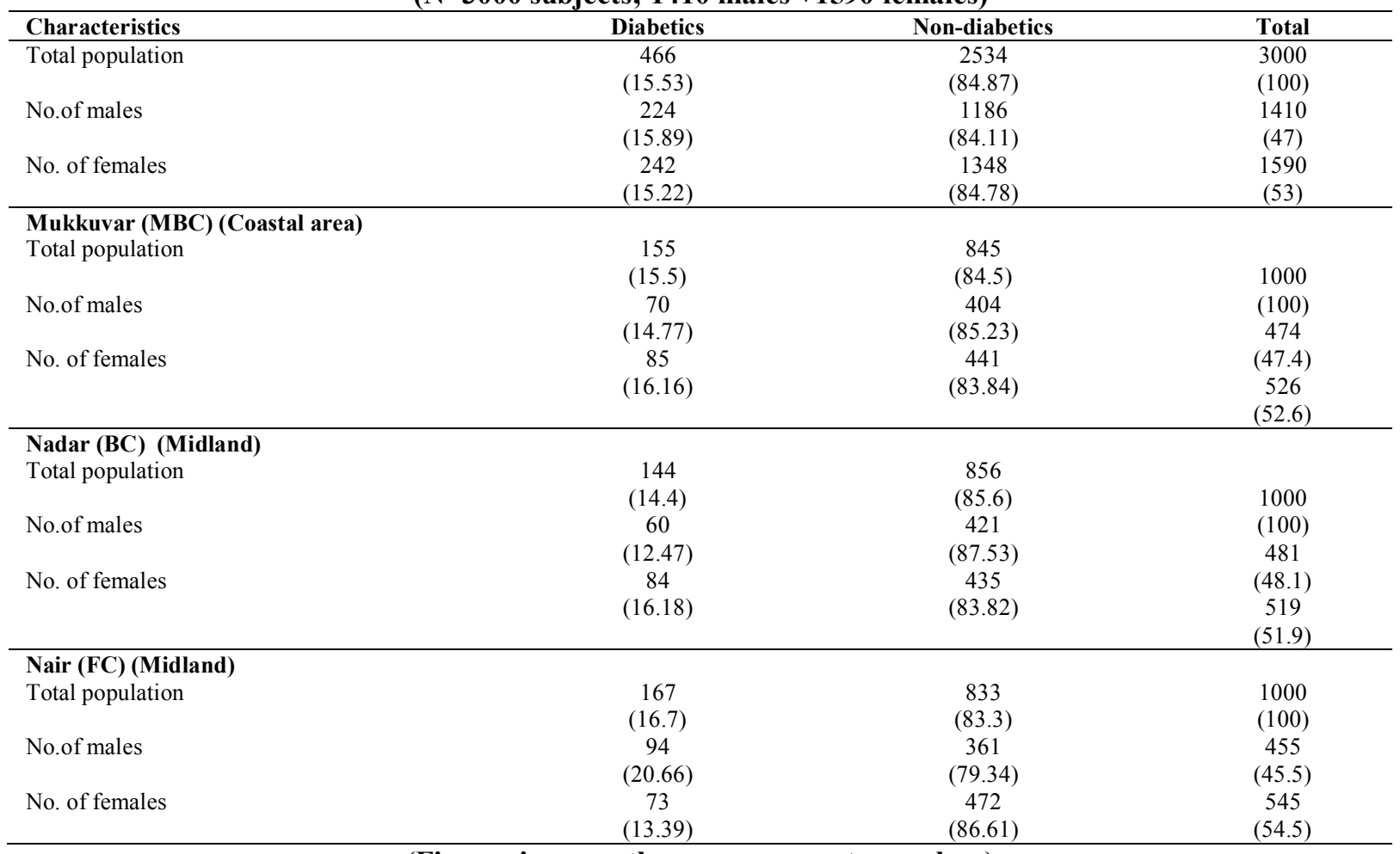

(Figures in parentheses are percentage values)

Table: 2 explains the age specific and hereditary onset of diabetes. ( $\mathrm{N}=3000$ subjects; 1410 males +1590 females)

\begin{tabular}{|c|c|c|c|}
\hline Characteristics & Diabetics & Non-diabetics & Total \\
\hline \multicolumn{4}{|l|}{$\begin{array}{l}\text { Age-group } \\
\text { (Yrs) }\end{array}$} \\
\hline $15-39$ & $\begin{array}{c}26 \\
(2.09)\end{array}$ & $\begin{array}{c}1216 \\
(97.9)\end{array}$ & $\begin{array}{c}1242 \\
(41.4)\end{array}$ \\
\hline $40-54$ & $\begin{array}{c}119 \\
(15.1)\end{array}$ & $\begin{array}{c}669 \\
(84.9)\end{array}$ & $\begin{array}{c}788 \\
(26.27)\end{array}$ \\
\hline $55-89$ & $\begin{array}{c}321 \\
(33.09)\end{array}$ & $\begin{array}{c}649 \\
(66.91)\end{array}$ & $\begin{array}{c}970 \\
(32.33)\end{array}$ \\
\hline \multicolumn{4}{|l|}{ Heridity } \\
\hline Father (D) & $\begin{array}{c}73 \\
(34.93)\end{array}$ & $\begin{array}{c}136 \\
(65.07)\end{array}$ & $\begin{array}{c}209 \\
(8.07)\end{array}$ \\
\hline Father (ND) & $\begin{array}{c}393 \\
(14.08)\end{array}$ & $\begin{array}{c}2398 \\
(85.92)\end{array}$ & $\begin{array}{c}2791 \\
(93.03)\end{array}$ \\
\hline Mother (D) & $\begin{array}{c}136 \\
(33.17)\end{array}$ & $\begin{array}{c}274 \\
(68.83)\end{array}$ & $\begin{array}{c}410 \\
(13.67)\end{array}$ \\
\hline
\end{tabular}


Type-2 Diabetes mellitus is it Habitat Specific?

\begin{tabular}{lccc} 
& & 276 & 698 \\
Parents (D) & 422 & $(39.54)$ & $(11.63)$ \\
Parents (ND) & $(60.46)$ & 5258 & 5302 \\
& 44 & $(99.17)$ & $(88.37)$ \\
\hline
\end{tabular}

(Figures in parentheses are percentage values)

(D-diabetic; ND-Non-diabetic) Yule's coefficient of association $(\mathrm{Q})$ : age group vs diabetics $=0.99$

Table.3.indicates some of the measurable parameters and diabetes. ( $\mathrm{N}=\mathbf{3 0 0 0}$ subjects; 1410 males +1590 females)

\begin{tabular}{lccc}
\hline Parameters & Diabetics & Non-diabetics & Total \\
\hline BMI & & & 96 \\
$\leq 18.5$ & 16 & 80 & $(3.2)$ \\
& $(16.67)$ & $(83.33)$ & 1682 \\
$18.51-24.9$ & 240 & 1442 & $(56.07)$ \\
& $(14.27)$ & $(85.73)$ & 937 \\
$25-29.9$ & 155 & 782 & $(31.23)$ \\
& $(16.51)$ & $(83.46)$ & 285 \\
$\geq 30$ & 55 & 230 & $(9.5)$ \\
& $(19.3)$ & $(80.7)$ & 307 \\
WHR & $37(12.05)$ & 270 & $(10.23)$ \\
$0.61-0.8$ & & $(87.95)$ & 2553 \\
& $391(15.32)$ & 2162 & $(85.1)$ \\
$0.81-1.0$ & & $(84.68)$ & 140 \\
& $38(27.14)$ & 102 & $(4.67)$ \\
$1.01-1.2$ & & $(72.86)$ & 817 \\
Systolic BP & $22(2.69)$ & 795 & $(27.23)$ \\
$\leq 119$ & & $(97.31)$ & 1213 \\
& & 1057 & $(40.43)$ \\
120 & $156(12.86)$ & $(87.14)$ & 970 \\
& & 682 & $(32.34)$ \\
\hline 121 & $288(29.69)$ & $(70.31)$ & \\
\hline
\end{tabular}

(Figures in parentheses are percentage values)

$\mathrm{r}:$ non-diabetics vs diabetics: WHR vs diabetics $=1$; Systolic BP vs diabetics $=1$

The age specific and hereditary nature of diabetes is depicted in table.2. The disease prevalence is $2.09 \%$ in $\leq 39 \mathrm{yr}$ old people, $15.1 \%$ in $40-54 \mathrm{yr}$ age group and $33.09 \%$ in $\geq 55 \mathrm{yr}$ aged persons. A high level of disease transmission (i.e.) $60.46 \%$ from the diabetic parents, while it is $14.08 \%$ through the non-diabetic fathers, $12.74 \%$ from the non-diabetic mothers and only $0.83 \%$ by the non-diabetic parents.

The prevalence of diabetes in $\leq 18.5,18.51-24.9,25-29.9$, and $\geq 30$ BMI categories are $16.67 \%$, $14.27 \%, 16.51 \%, 19.3 \%$ respectively. Similarly $12.05 \%$ diabetic cases are seen in $0.61-0.8$ WHR group, $15.32 \%$ in $0.81-1.0$ WHR category and $27.14 \%$ in 1.01-1.2 WHR division. The diseased cases in systolic blood pressure groups $\leq 119(\mathrm{~mm} \mathrm{Hg}), 120(\mathrm{mmHg})$ and $\geq 121(\mathrm{mmHg})$ are $2.69 \% 12.86 \%, 29.69 \%$ respectively (Table.3).

Table.4. reveals some prominent socio-economic criteria on diabetes.

( $\mathrm{N}=3000$ subjects; 1410 males +1590 females)

\begin{tabular}{lccl}
\hline Parameters & Diabetics & Non-diabetics & Total \\
\hline Economic criteria & & & \\
Poor class & 324 & 1664 & 1988 \\
& $(16.3)$ & $(83.7)$ & $(66.27)$ \\
Middle class & 138 & 861 & 999 \\
& $(13.81)$ & $(86.19)$ & $(33.3)$ \\
Upper class & 4 & 9 & 13 \\
& $(30.77)$ & $(69.23)$ & $(0.43)$ \\
Habits & 141 & & \\
Teetotallers & $(6.73)$ & 1954 & 2095 \\
Alcohol plus smoking & 114 & $(93.27)$ & $(69.83)$ \\
& $(35.63)$ & 206 & 320 \\
Smoking & 81 & $(64.37)$ & $(10.67)$ \\
& $(13.85)$ & 504 & 585 \\
Vegans & 16 & $(86.15)$ & $(19.5)$ \\
& $(24.62)$ & 49 & 65 \\
Mixed diet users & 450 & $(75.38)$ & $(2.17)$ \\
& $(15.33)$ & 2485 & 2935 \\
\end{tabular}

(Figures in parentheses are percentage values)

$\chi^{2}$ test : non-diabetics vs diabetics (habits) $\mathrm{p}<0.05$ 
Results show that the prevalence of diabetes in poor, middle and upper classes are $16.3 \%, 13.81 \%$, $30.77 \%$ respectively. Likely it is about $6.73 \%$ among teetotalers, $13.85 \%$ in smokers and $35.63 \%$ in people with alcohol and smoking habits. The study further reveals that $15.33 \%$ diabetics are found as mixed diet users and $24.62 \%$ are vegans (Table.4).

\section{Discussion}

Diabetes has emerged as one of the deadliest life threatening diseases to the mankind. The alarming rate of its prevalence $(1,2)$ and the death and disability (3) caused by this disease is not a new one to the global community. The disease has already shattered the lives of countless number of Indians with a highest prevalence $(1,2)$ and become an epidemic in India(3).

Epidemiological studies on the spatial or geographical distribution (i.e.) midland and coastal areas are only limited to identify the extent of this disease status in these habitats. Studies have claimed a moderate to severe rate of prevalence of diabetes around the globe. It is reported as $1.2 \%(35), 2.4 \%(36), 2.8 \%(15)$, $8.12 \%(9), 8.6 \%$ (7), $11.6 \%(37), 12.1 \%$ (38) and $16.3 \%$ (5) by previous studies, but the overall disease prevalence in the present study is $15.53 \%$.

Studies indicate that the prevalence of diabetes in the coastal areas is $2.5 \%$ (39) and $16 \%$ (40), while it is $15.5 \%$ in the current study. Around $8.1 \%$ (39) and $13.1 \%$ (41) disease prevalence is observed in midland areas, while it is $15.5 \%$ in the present study. An equitable level of disease prevalence (i.e. $15.5 \%$ ) is recorded in our midland and coastal study areas and the disease is found as a habitat non-specific one.

Diabetes prevalence among sexes is still an obscure. Female $(5,35,42)$ and male sex specific incidence $(9,15,20)$ of diabetes is reported by earlier researchers. A slightly male sex specific $(15.89 \%)$ incidence of diabetes is recorded in the present study than the females $(15.22 \%)$. But female sex specific occurrence of diabetes is found in our coastal Mukkuvar community $(16.16 \%)$ and in the midland Nadar community $(16.18 \%)$, but it is male specific (20.66\%) in midland Nair community. Our study also supports the earlier findings (39) of Kutty VR., et.al.(2000). Communitywise prevalence of diabetes in different habitats indicates that the disease is not confined to any sex.

Age related increase of diabetes prevalence is reported by earlier researchers $(14,15,40,43,44)$. It is true in our study also. Previous studies explain the predominant maternal transmission of Type-2 Diabetes mellitus $(17,45,46)$. But there is no sharp difference between paternal and maternal inheritance of diabetes in our study.

Earlier reports explained the active role of obesity on the incidence of diabetes (47-50), but our study contradicts this finding. WHR, one of the key factors in health related issues on diabetes is reported by some studies $(51,52)$. A positive association has been observed between WHR and our diabetic cases $(r=1)$.

A strong positive association between hypertension and diabetes has been reported by earlier researchers $(23,53)$. Our study corroborates this finding, where the link between systolic blood pressure and diabetes is well documented ( $\mathrm{r}=1)$. Reports say diabetes is two times more prevalent in low income than the high income populations $(54,55)$. Our study contradicts these reports, but supports the other findings which indicates that diabetes prevalence is more among high socio-economic populations (40).

Reports explain the active role of alcohol (56) and smoking on diabetes prevalence in populations (57). A strong association is seen between different habits and our diabetic subjects $(p=<0.05)$. A low level of diabetes prevalence is reported by earlier researchers among vegans $(18,19)$. But there is no impact of vegan diet on the incidence of diabetes in our spatially distributed population (i.e.) midland and coastal population.

The reported causes such as metabolic syndrome, heredity, obesity, low socio-economic status, bad habits like smoking and alcohol and sedentary lifestyle are thought to be the main culprits for the onset and prevalence of diabetes in the society. But, most of our diabetic victims are normal and /or underweight subjects, with high socio-economic status, teetotalers and hard working people and not with metabolic syndrome and hereditary predisposition. If so, who is the culprit for the prevalence, surge and the emergence of new cases, the individuals (or) their parents (or) their environment?. For these questions doubt still prevails over the identification of the real culprit(s) for this modern human menace. Elaborate studies are essential to find out the main culprits and curb diabetes from the globe.

\section{Conclusion}

The findings of the present study is put forward as a hypothesis(i.e.) 'culprit hypothesis' concludes that almost all the factors which are contributed by the individual, his genes and his environment may act as the 'culprits' who are partly and/or equally responsible for the disturbance of normal metabolism and in turn the onset of this deadly disease, which spurts as a pandemic in the modern days. The study also confirmed the habitat non-specific occurrence of diabetes. 

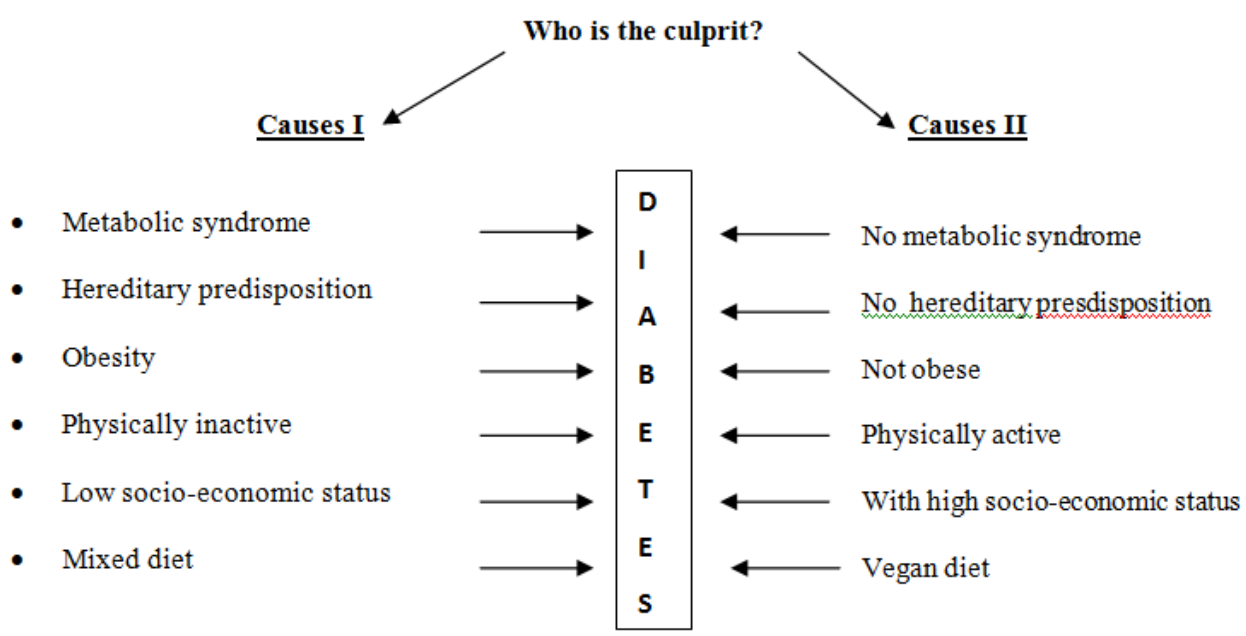

Acknowledgement

Thanks are due to University Grants Commission, New Delhi for financial assistance.

\section{References}

[1] Wild S., Roglic G., Green A., Sicree R. and King H. 2004. Global prevalence of diabetes: Estimates for the year 2000 and projections for 2030. Diabetes Care; 27:1047-53.

[2] Huizinga MM and Rothman RL. 2006. Addressing the diabetes pandemic : A comprehensive approach. Ind.J.Med.Res;124; 124: 481-84.

[3] King H., Aubert RE. and Herman WH. 1998. Global burden of diabetes, 1995-2005: prevalence, numerical estimates and projections. Diabetes Care; 21:1414-31.

[4] Zimmet PK., Albert KG. and Shaw J. 2001. Global and societal implications of the diabetes epidemic. Nature; 414:782-87.

[5] Ramankutty VA., Joseph A., and Soman CR. 1999. High prevalence of Type -2 diabetes in an urban settlement in Kerala, India. Ehn. Health; 4:231-39.

[6] Ramachandran A., Jali MV., Mohan V., Snehalatha C., and Viswanathan M. 1988. High prevalence of diabetes in an urban population in South India. BMJ; 297:587-90.

[7] Gupta A., Gupta R., Sarna M., Rastogi S., Gupta VP., and Kothari K. 2003. Prevalence of diabetes, impaired fasting glucose and insulin resistance syndrome in an urban Indian population. Diabetes Res. Clinc. Pract; 61: 69-76.

[8] Menon VU., Kumar KV., Gilchrist A., Sugathan TN., Sundaram KR., Nair V., et.al.2006. Prevalence of known undetected diabetes and associated risk factors in central Kerala - ADEPS. Diabetes Res.Clin.Pract; 74:289-94.

[9] Jerlin Nirmala F., Murugan A. 2011. Incidence of Type-2 diabetes in an agrarian community in the sourthern most parts of India. Aus.J.Basic.Appl. Sci; 5(11); 417-23.

[10] American Diabetes Association. 2006. Diagnosis and classification of D.mellitus. Diabetes Care; 29:S43- S48.

[11] Colditz GA., Willet WC., Rotnitzky A and Manson JE. 2007. Weight gain as a risk factor for clinical Diabetes mellitus in women. Ann. Intern. Med; 122: 481-86.

[12] Nasraway SA Jr., Albert M., Donelly AM., Ruthazer R., Shikora SA and Saltzman E. 2006. Morbid obesity is an independent determinant of death among surgically critical ill patients. Crit. Care Med; 34 : 964-70.

[13] Mohan D., Raj D., Santhirani CS., Datta M., Unwin C., Kapur A., et. al. 2005. Awareness and knowledge of diabetes in Chennai the Chennai Urban Rural Epidemiology Study (CURES-9). J. Assoc. Physicians. India; 53: 283-87.

[14] Burrows NR., Geiss LS., Engelgau MM., and Acton KJ. 2000. Prevalence of diabetes among native Americans and Alaska natives 1990-97 : an increasing burden. Diabetes Care; 23: 1786-90.

[15] Chow CK., Raj PK., Raju R., Reddy KS., Cardona M., Celermejei DS and Neal BC. 2006. The prevalence and management of diabetes in rural India. Diabetes care; 29: 1717-18.

[16] Permutt MA., Wasson J and Cox N. 1994. Genetic epidemiology of diabetes (review). J. Clin. Invest; 115: 1431-39.

[17] Charles MA., Pettitt DJ., Hanson RL., Bennet PH., Saad MF., LiU QZ and Knowler WC. 1994. Familial and metabolic factors related to BP in Pima Indian children. Am. J. Epidemiol; $140: 123-31$.

[18] Snowdown DA., and Philips RL. 1985. Does a vegetarian diet reduce the occurrence of diabetes. Am.J.Pub.Health; 75(5) : 507-12.

[19] Nicolson A., Sklar M., Barnard N., Gore S., Sullivan R and Browning S. 1999. Toward improved management of NIDDM : a randomised, controlled, pilot intervention using a low fat vegetarian diet. Preventive medicine; 29(2) : 87-91.

[20] Galting W., Budd S., Walters D., Mullee MA., Goddard JR and Hill RD. 1998. Evidence of an increasing prevalence of diagnosed DM in the Poole area from 1983-1996. Diab. Med; $15: 1015-21$.

[21] Skadek R., Rocheleau G., Rung J., Dina C., Shen L., Serre D., et.al. 2007. A genomewide association study identifies noval risk loci for Type -2 diabetes. Nature; 445:881-85.

[22] Winkelby M and Cubbin C. 2003. Influence of individual and neighbourhood socio-economic status on mortality among black, Mexican American and white women and men in the United States. J. Epidemiol. Com. Health; 57:442-52.

[23] Epstein M and Sowers JR. 1992. Diabetes mellitus and hypertension. Hypertension; 19:403-18.

[24] www.en.wikipedia.org/wiki/kanyakumari_district

[25] Thurston E.1987. Castes and Tribes of Southern India.Vol.V., edited by K. Rangachari, Asian educational service : New Delhi.

[26] Iyer LK. Ananthakrishna. 1909. The Cochin tribes and castes. Vol. I. Higginbothams, Madras.

[27] Nagam Aiya V. 1906. The Travancore State Manual, Vol. I, Government Press, Trivandrum.

[28] www.kanyakumari.tn.nic.in/coastal.html

[29] Jeeva S and Femila V. 2012. Ethnobotanical investigation of Nadars in Atoor village, Kanyakumari district, Tamil Nadu, India. Asian Pacific J. Trop. Biomed; S593-S600. 
[30] www.history of nairs. blogspot.in/2009/08history of - nairs - community - from-kerala.html

[31] 77 Elektronica Ltd., 1116, Budapest, Hungary.

[32] WHO Expert Committee. Physical status : the use and interpretation of anthropometry. 1995. WHO.Tech. Rep.Serv; 854: 424-38.

[33] National High Blood Pressure Education Programme. The seventh report of the Joint National Committee for detection, evaluation and treatment of high blood pressure. 2003. JAMA; 289:2560-72.

[34] www.tekisimizanaliz.com

[35] Murugan. A., and Beula A. 2012. Epidemiological studies on Type-2 Diabetes mellitus in Kaanitribes of Kanyakumari district, Tamil Nadu, India. IJRRPAS; 2(4) : 651-61.

[36] Sridhar GR., Rao PV and Ahuja MMS.2002. Epidemiology of diabetes and its complications. In : RSSDI Text Book of DM, Hyderabad. Research Society for the Study of Diabetes in India; 95-112.

[37] Ramachandran AC., Snehalatha E., Latha V., Vijay V., and Viswanathan M.1997. Rising prevalence of NIDDM in an urban population in India. Diabetologia, 40:232-37.

[38] Albert KG and Zimmet PZ. 1998. Definition, diagnosis and classification of DM and its complications. Part I. Diagnosis and classification of DM, provisional report of WHO consultation. Diabetes Med; 15:539-53.

[39] Kutty VR., Soman CR., Joseph A., Pisharody R., and Vijayakumar K.2000. Type-2 diabetes in Southern Kerala : Variation in prevalence among geographic divisions within a region. Natl.Med.J.India; 13(6) : 287-92.

[40] Rao CR., Kamath VG., Shetty A., and Kamath A. 2010. A study on the prevalence of Type-2 diabetes in coastal Karnataka. Int.J.Diab.Dev. Countries; 30(2) : 80-85.

[41] Tiwari RR., Deb PK., Debbarma A., Chaudhuri R., et.al. 2008. Risk factor analysis in self reported diabetes in a rural Kerala population. Int.J.Diab.Dev. Countries; 28(3) : 91-94.

[42] Ramachandran A., Snehalatha C., Dharmaraj D., and Viswanathan M. 1992. Prevalence of glucose intolerance in Asian Indians. Urban rural difference and significance of upper body adiposity. Diabetes Care; 15:1348-55.

[43] Amoah AG., Owusu SK., and Adjei S. 2002. Diabetes is Ghana : A community based prevalence study in Greater Accra. Diab.Res.Clin.Pract; $56:$ 197-205.

[44] Basavanagowdappa H., Prabhakar AK., Prasannaraj P., Gurudev KC., et.al.2005. Study of prevalence of D.mellitus and impaired fasting glucose in a rural population. Int. J. Diab. Dev.Countries; 25:98-101.

[45] Bao W., Srinivasan SR., Wattigney WA and Berenson GS. 1995. The relation of parental cardiovascular disease risk factors in children and young adults : the Bongalusa Heart Study. Circulation; 91: 365-71.

[46] Klein BE., Klein R., Moss SE., and Cruickshanks KJ. 1996. Parental history of diabetes in a population based study. Diabetes Care; 19:827-30.

[47] Colditz GA., Willett WC., Rotnitzky A., and Manson JE. 1995. Weight gain as a risk factor for clinical Diabetes mellitus in women. Ann. Intern. Med; $122:$ 481-86.

[48] Gregg EW., Cheng YJ., Cadwell BL., Imperatore G., Williams DE., Flegal KM., et.al.2005. Secular trends in cardiovascular disease risk factors according to body mass index in US adults. JAMA; 293: 1868-74.

[49] Hartz AJ., Rupley DC. JR., Kalkhoff RD., and Rimm AA. 1983. Relationship of obesity to diabetes:influence of obesity level and body fat distribution. Prev.Med; 12:351-57.

[50] Holbrook TL., Barrett-Connor E., and Wingard DL. 1989. The association of lifetime weight and weight control patterns with diabetes among men and women in an adult community. Int.J. Obes; $13: 723-29$.

[51] Misra A., and Vikram NK. 2004. Insulin resistance syndrome (metabolic syndrome) and obesity in Asian Indians : Evidence and implications. Nutrition; 20: 482-91.

[52] Sayeed MA., Banu A., Malek MA., and Khan AK. 1998. Blood pressure and coronary heart disease in NIDDM subjects at diagnosis : prevalence and risk in Bangaladeshi population.Diab.Res.Clin.Pract; 39: 147-55.

[53] Williams B. 1994. Insulin resistance : the shape of things to come.Lancet: 344:521-24

[54] Robbins JM., Vaccarino V., Zhang H and Kasl V. 2001. Socio-economic status and T2DM in African American and Non-hispanic white women and men. Evidence from the Third National Health and Nutrition Examination Survey. Am.J.Pub.Health; 91(1) : 7683.

[55] Stelmach W., Kaczmarczyk - Chalas K., Bielecki W and Drygas W. 2005. How education, income control over life and lifestyle contribute to cardiovascular risk factors in adults in post-Communist country. Pub. Health; 119: 498-508.

[56] Swade TF and Emanuele NY. 1997. Increase impotence, retinopathy, and possibly peripheral neuropathy, hypertriglyceridemia, ketoacidosis and worsens diabetic control. Alcohol and diabetes. Compr. Ther; 23(2) : 135-40.

[57] Muhlhauser I. 1994. Cigarette smoking and diabetes : an update. Diabet.Med; 11: 336-43. 